\title{
Surface Appendages Similar to Fimbriae (Pili) on Pseudomonas Species
}

\author{
By J. A. FUERST AND A. C. HAYWARD \\ Department of Microbiology, University of Queensland, \\ Brisbane, Australia 4006
}

(Accepted for publication I6 June 1969)

\section{SUMMARY}

Twenty-two strains of Pseudomonas, representing I 5 species, were examined by electron microscopy, utilizing the techniques of negative contrast staining and to a lesser extent shadowing and ultrathin sectioning. Fimbria-like appendages were found on cells of $\mathrm{I} 2$ strains, representing 8 species. Polar, fimbrialike filaments were observed on Pseudomonas aeruginosa, $P$. acidovorans, $P$. testosteroni, $P$. maltophilia, $P$. alcaligenes and $P$. solanacearum. Peritrichous filaments were found on $P$. multivorans and $P$. fragi.

\section{INTRODUCTION}

Bacterial fimbriae or pili are filamentous appendages of bacterial cells which differ from flagella in a number of ways. Fimbriae do not exhibit the sinuous form characteristic of bacterial flagella and they are apparently not related to the motility of flagellated bacteria (Brinton, 1965; Duguid, Anderson \& Campbell, 1966). Fimbriae are often thinner than flagella and may differ from flagella in detailed fine structure (Duguid, Smith, Dempster \& Edmunds, 1955; Brinton, 1967). Like flagella, fimbriae may be of polar or peritrichous distribution, depending on the genus or species of bacterium examined (Houwink \& van Iterson, 1950). There is no convincing evidence at present of the occurrence of fimbriae in other than Gram-negative bacteria.

Much recent work has been concentrated on fimbriae of the enterobacteria and, with notable exceptions (e.g. Schmidt, I966; Tweedy, Park \& Hodgkiss, I968), the polar flagellates have been relatively neglected. Fimbriae have been reported on only four Pseudomonas species; Pseudomonas aeruginosa (Houwink \& van Iterson, 1950; Bradley, 1965, 1966); $P$. echinoides (Marx \& Heumann, 1962; Heumann \& Marx, 1964), $P$. piscicida (Hansen, Ingebritsen \& Weeks, 1963) and P. multivorans (Tweedy et al. 1968). It would seem that the majority of Pseudomonas species have not been examined systematically using appropriate methods. In order to extend existing knowledge of the occurrence of fimbriae in Pseudomonas, fifteen physiologically diverse species of the genus were examined by electron microscopy as part of a survey of the filamentous appendages found on the surface of pseudomonad cells. The techniques of negative contrast staining and to a lesser extent shadowing and ultrathin sectioning were used.

Like Tweedy et al. (1968), we do not wish to imply through use of the term fimbriae for filamentous appendages other than flagella on pseudomonads that such appendages are comparable in every respect to the fimbriae of other organisms. We also use 
'fimbriae' (Duguid et al. 1955) rather than 'pili' because it has priority and because we accept the other arguments (Duguid, 1966; Duguid \& Anderson, 1967) in favour of this term.

\section{METHODS}

Organisms and media. The organisms examined in this study, as listed in Table I, were grown in either peptone yeast extract broth (Difco bacto peptone, 10.0 g.; Difco bacto yeast extract, $5.0 \mathrm{~g}$.; $\mathrm{NaCl}, 5 \cdot 0 \mathrm{~g}$.; distilled water I 1.; $\mathrm{pH} 7 \cdot 2$ ), sucrose peptone broth (sucrose, $20.0 \mathrm{~g}$.; Difco bacto peptone, 5.0 g.; $\mathrm{MgSO}_{4} .7 \mathrm{H}_{2} \mathrm{O}$, 0.25 g.; $\mathrm{K}_{2} \mathrm{HPO}_{4}$, $0.5 \mathrm{~g}$.; distilled water $\mathrm{I} 1 . ; \mathrm{pH} 7.0$ to 7.2 ), $0 . \mathrm{I} \%$ lactate mineral salts medium (lactic acid, I g./1.; standard mineral base of Stanier, Palleroni \& Doudoroff, I966), or 0. I \% lactate mineral salts medium supplemented with $0.025 \%$ DL-methionine (for Pseudomonas maltophilia only).

\section{Table I. Pseudomonas species examined for fimbriae}

\begin{tabular}{|c|c|c|}
\hline Strain no. & Organism & Culture collection no. or source \\
\hline $85^{*}$ & $P$. aeruginosa & ATCC I4216; NCIB 9685 \\
\hline $80^{*}$ & P. aeruginosa & ATCC IOI $45 ;$ CCEB $48 \mathrm{I} ;$ NCIB $8295 ;$ NCTC 10332 \\
\hline $67^{*}$ & P. fuorescens & CCEB 488-A; ATCC 15456; NCBB 9886 \\
\hline $62 *$ & P. fluorescens & ATCC 13525; NCIB 9046; NCTC 10038 \\
\hline $64^{*}$ & P. chlororaphis & NCIB 9392; ATCC 9446; NRRL B-560 \\
\hline $70^{*}$ & P. aureofaciens & NCIB 9030; ATCC I 3985; NRRL B-1576; Delft E. III. 9.25.I \\
\hline $86^{*}$ & P. putida & CCEB 520; NCIB 9887 \\
\hline $83^{*}$ & P. putrefaciens & NCIB 86 I5 \\
\hline $72^{*}$ & P. acidovorans & Den Dooren De Jong strain 7; NCIB 968I ; ATCC I 5668 \\
\hline $81^{*}$ & P. testosteroni & NCIB 8955; ATCC I 1996; NRRL B-26I I \\
\hline $75^{*}$ & P. oleovorans & ATCC $8062 ;$ NCIB 6576 \\
\hline $58^{*}$ & $P$. alcaligenes & ATCC $14909 ;$ NCTC I0367 \\
\hline 0346 & P. multivorans & $\begin{array}{l}\text { Isolated from forest-litter, Mt. Nebo, Queensland, Australia, } \\
\text { in May } 1968\end{array}$ \\
\hline 036B & P. multivorans & $\begin{array}{l}\text { Isolated from tomato stems from Cairns, Queensland, } \\
\text { Australia in October } 1965\end{array}$ \\
\hline $56^{*}$ & P. fragi & ATCC $4973 ;$ CCEB $387 ;$ NCIB $8542 ;$ NRRL B-25 \\
\hline $\begin{array}{l}0147 \\
61^{*}\end{array}$ & $\begin{array}{l}\text { P. maltophilia } \\
P . \text { maltophilia }\end{array}$ & $\begin{array}{l}\text { From Commonwealth Serum Laboratories, Parkville, Victoria } \\
\text { ATCC 13637; NCIB 9203; NCTC } 10257\end{array}$ \\
\hline $017 \mathrm{~A}$ & P. solanacearum & From bacterial wilt of potato, isolated, April 1965 . Biotype II \\
\hline $002 \mathrm{~A}$ & P. solanacearum & From bacterial wilt of tomato, April 1965. Biotype III \\
\hline $003 \mathrm{~A}$ & $P$. solanacearum & From bacterial wilt of ginger, April 1965. Biotype IV \\
\hline 450 & P. stizolobii & $\begin{array}{l}\text { NCPPB } 450 ; \text { W. H. Burkholder PS } 23 \text { isolated from Trifolium } \\
\text { repens in U.S.A., } 1954\end{array}$ \\
\hline $0268 \mathrm{~A}$ & P. stizolobii & $\begin{array}{l}\text { Isolated from blackened stems of Vicia sativa cultivar Golden } \\
\text { Tares, April I967. From Wollongbar Agric. Res. Station, } \\
\text { N.S.W. Dept Agric. }\end{array}$ \\
\hline
\end{tabular}

Organisms to be examined by negative contrast staining or shadowing in the survey for fimbriae were grown through various serial subcultures in $6 \times \frac{1}{2}$ in. test tubes containing 5 or $10 \mathrm{ml}$. medium and incubated aerobically at $28^{\circ}$. Cells for ultrathin sectioning were grown in $100 \mathrm{ml}$. medical flats containing $10 \mathrm{ml}$. of $0 . \mathrm{I} \%$ lactate mineral salts medium and incubated aerobically at $28^{\circ}$ on their wide sides. The exact ages of each culture examined are listed in the 'Explanation of Plates'. Initial inocula in all cases were from stock agar slope cultures. Purity checks were performed on all 
cultures examined by plating out from the culture itself or from the washed cell suspension prepared from the culture (see below).

Negative contrast staining. Cells to be examined were harvested by centrifugation, washed once in sterile distilled water before final resuspension in the wash fluid. A $1 \%$ solution of sodium phosphotungstate $(\mathrm{pH} 6.0,7.0$ or 7.4 ) containing bovine plasma albumin to $0.03 \%$ was employed as a negative contrast stain. Negative contrast preparations were usually made by applying a drop of washed bacterial suspension to a carbon-coated copper grid. After allowing up to $3 \mathrm{~min}$. for adherence of cells to the carbon film to take place, excess fluid was removed with filter paper. A drop of negative contrast stain was then applied to the grid and excess fluid again removed. The grid was then transferred to the electron microscope specimen chamber where final drying was allowed to take place. In some cases the negative contrast agent was applied to the grid first (see below).

Shadowing. A drop of washed bacterial suspension (prepared in the same manner as for negative contrast staining, with the exception that in some cases $0.1 \%$ formalin was used as a wash fluid) was applied to a carbon-coated grid and excess fluid removed. The preparation was then shadowed with platinum/carbon. The angle of shadowing was not determined.

Ultrathin sectioning. After $26 \mathrm{hr}$ growth in $100 \mathrm{ml}$. medical flats containing $10 \mathrm{ml}$. of $0.1 \%$ lactate mineral salts medium incubated aerobically at $28^{\circ}$, cells were harvested by centrifugation. Pelleted cells were fixed with $4 \%(\mathrm{w} / \mathrm{v})$ glutaraldehyde buffered to pH 6.2 with 0.I M-sodium cacodylate (Sabatini, Bensch \& Barrnett, 1963). Fixation was allowed to proceed for $18 \mathrm{hr}$ at room temperature. Cells were then washed in $0.2 \mathrm{M}$-sucrose solution buffered to $\mathrm{pH} 6.2$ in $0 . \mathrm{I} \mathrm{M}$-cacodylate buffer and postfixation was carried out in osmium tetroxide overnight. After postfixation, cells were washed in $0.5 \%$ uranyl acetate for $\mathrm{I}$ hr. Dehydration was performed via a series of ethanol solutions and the pellet was embedded in Epon 812 by a method similar to that of Luft (I96I). Sections were cut from the resulting block on a Porter-Blum ultramicrotome. Sections were poststained with $5 \%(\mathrm{w} / \mathrm{v})$ uranyl acetate for $15 \mathrm{~min}$. and lead citrate (Reynolds, 1963) for 2 min.

Electron microscopy. A Siemens Elmiskop IA was used at accelerating voltages of $80 \mathrm{kV}$ or $100 \mathrm{kV}$.

Standard procedures for obtaining statistically analysable fimbrial diameter measurements. Organisms were grown for $48 \mathrm{hr}$ in $6 \times \frac{1}{2} \mathrm{in}$. tubes containing $5 \mathrm{ml}$. of peptone yeast extract broth and incubated aerobically at $28^{\circ}$. Cells were harvested by a standard method and purity checks performed. All preparations were negatively stained with I $\%$ sodium phosphotungstate $(\mathrm{pH} 7.0)$ containing $0.03 \%$ bovine plasma albumin, applied by a standardized procedure. All micrographs of standard preparations were taken at an instrumental magnification of $\times 80,000$. Measurement of fimbrial diameters was made from prints enlarged $\times 2$, using a Peak Scale Lupe $7 \times$ (Kellner type) micrometer with a linear graticule. For determination of means and standard deviations, thirty diameters were measured in each case.

\section{RESULTS}

Survey for fimbria-like appendages in Pseudomonas species. Negatively stained preparations of all the strains listed in Table I were examined exhaustively in the 
electron microscope for fimbriated cells. Among the criteria used to distinguish fimbriae were: (i) position (i.e. surface appendages); (ii) shape (i.e. showing no regular undulations); (iii) diameter (i.e. thinner than flagella); (iv) substructure (i.e. a substructure differing from that of flagella of the same species); (v) distribution (only if fimbrial distribution differed from the flagellar distribution of the same species). Results of the survey are summarized in Table 2. At least 12 out of the 22 strains examined, representing 8 of 15 species, definitely possessed fimbria-like appendages. Appendages thinner than flagella were seen on one strain of Pseudomonas stizolobii (strain $0268 \mathrm{~A}$ ) but these filaments were of variable diameter and seemed to taper in some cases. They were only seen in very old cultures and there is a definite possibility that they are an artifact resulting from autolytic effects or represent slime material.

\begin{tabular}{|c|c|c|}
\hline $\begin{array}{l}\text { Bacterial } \\
\text { strain }\end{array}$ & $\begin{array}{l}\text { Fimbriae } \\
\text { observed }\end{array}$ & Distribution \\
\hline P. aeruginosa $(85)$ & + & Polar \\
\hline P. aeruginosa (80) & + & Polar \\
\hline P. fluorescens (67) & - & . \\
\hline P. fluorescens (62) & - & . \\
\hline P. chlororaphis (64) & - & . \\
\hline P. aureofaciens $(70)$ & - & . \\
\hline P. putida (86) & - & . \\
\hline P. putrefaciens $(83)$ & - & \\
\hline P. acidovorans (72) & + & Polar \\
\hline P. testosteroni (8I) & + & Polar \\
\hline P. oleovorans (75) & - & \\
\hline$P$. alcaligenes $\left(5^{8}\right)$ & + & Polar \\
\hline P. multivorans (0346) & + & Peritrichous \\
\hline P. multivorans (036B) & + & Peritrichous \\
\hline P. fragi $(56)$ & + & Peritrichous \\
\hline P. maltophilia (OI47) & + & Polar \\
\hline P. maltophilia (6r) & - & $\cdot$ \\
\hline \multicolumn{3}{|l|}{ P. solanacearum } \\
\hline biotype II (OI7 A) & + & Polar \\
\hline biotype III $(002 \mathrm{~A})$ & + & Polar \\
\hline biotype IV (003 A) & + & Polar \\
\hline P. stizolobii (0268 A) & $?$ & $?$ \\
\hline P. stizolobii $(450)$ & - & . \\
\hline
\end{tabular}

In a number of strains, attempts to demonstrate fimbriae gave negative results, even after examination of cells grown by several different subculturing procedures and/or in different media. Negative results such as those obtained must be interpreted cautiously for a number of reasons, however (see Discussion), and do not necessarily mean that the organisms are genotypically incapable of synthesizing fimbriae. Among those strains in which fimbriae were found, fimbriation of all cells in a sample was never observed. Usually the majority of cells examined in a preparation were not fimbriated. This perhaps emphasizes the dangers of misinterpreting negative results and the necessity for exhaustive scanning of preparations in a survey for fimbriation.

Polar and peritrichous distributions of fimbriae on individual cells were observed. Where distribution was polar, fimbriae were found on the flagellated pole only, except in the case of strain 85 of Pseudomonas aeruginosa and possibly strain $002 \mathrm{~A}$ of 
P. solanacearum. Bipolar fimbriae were sometimes found on cells of strain 85 of $P$. aeruginosa. Distribution of fimbriae on pseudomonad cells cannot be related in any predictable way to flagellar distribution, apparently, since all the species of Pseudomonas examined possessed polar flagella while cells of at least two species possessed peritrichous fimbriae.

In no case did fimbriae on Pseudomonas species display a sinuous outline with regular undulations. Fimbriae (especially those of polar distribution) were sometimes seen to be slightly curved or irregularly bent in certain portions. It may be that these filaments are flexible rather than rigidly straight; distortion may result from stress during drying in the course of preparation.

\section{Table 3. Diameters of fimbriae found on Pseudomonas species} by negative contrast staining

$$
\begin{aligned}
& P . \text { aeruginosa }(85) \\
& P . \text { aeruginosa }(80) \\
& P . \text { multivorans }(0346) \\
& P . \text { solanacearum }(017 \mathrm{~A}) \\
& P . \text { solanacearum }(002 \mathrm{~A}) \\
& P . \text { solanacearum }(003 \mathrm{~A}) \\
& P . \text { testosteroni }(8 \mathrm{I}) \\
& P . \text { alcaligenes }(58)
\end{aligned}
$$

$$
\begin{aligned}
& 54 \pm 14 \AA \\
& 52 \pm 14 \AA \\
& 62 \pm 5 \AA \\
& 49 \pm 9 \AA \\
& 55 \pm 10 \AA \\
& 60 \pm 9 \AA \\
& 40 \pm 8 \AA \\
& 65 \pm 20 \AA
\end{aligned}
$$

\footnotetext{
Values for measured diameters of fimbriae ( 30 diameters measured for each value) are given as the mean \pm the standard deviation. Measurements for these values were of fimbriae on cells grown and negatively stained by a standard procedure (see Methods).
}

Although there may be error in determination of the maximum number and length of fimbriae on individual cells, due to possible breakage of fimbriae, some general observations can perhaps be made. The maximum number of fimbriae observed on either strain of Pseudomonas multivorans was greater than 100/cell. About 30 fimbriae/cell was the maximum observed on P. fragi. Among those strains with polar fimbriae, however, more than Io fimbriae/cell were never observed (Io/cell were only observed on strain 85 of $P$. aeruginosa). The maximum fimbrial length observed never exceeded $\mathrm{I} \cdot 7 \mu$ on any strain.

The diameters of fimbriae seen in negative contrast preparations are given for several strains in Table 3. They are all below the diameters observed for the flagella of these strains, and are also below the range of published diameters of unsheathed flagella, i.e. $120 \AA$ (Hoeniger, 1965) to $220 \AA$ (Richter \& Kress, 1967).

Substructure of fimbriae seen in negative contrast preparations. Fimbrial substructure was clearly discerned in only a few species. In most cases substructure was not visible or very obscure.

The fimbriae of Pseudomonas testosteroni and $P$. fragi exhibited substructures of a periodic nature suggesting that they are composed of repeating subunits of some kind (Pl. I, fig. 2, Pl. 5, fig. IO).

Dark central lines were observed in the fimbriae of Pseudomonas multivorans (Pl. 3, fig. 6) and $P$. fragi (Pl. 5, fig. I0), when seen in negative contrast preparations. The central regions were 13 to $19 \AA$ wide in both species. It is perhaps significant that dark central lines were never seen in the polar fimbriae of other species. Bradley (I966) stated that the fimbriae of $P$. aeruginosa which he observed in negative contrast 
preparations appeared to be hollow in places. This was not observed in the fimbriae of either strain of $P$. aeruginosa examined in this study,

The flagella of the Pseudomonas species examined were either sheathed or unsheathed. Sheathed flagella were found only on strains of $P$. stizolobii (Fuerst \& Hayward, 1969). Where substructure of unsheathed flagella was visible, it usually consisted of an aggregate of globular subunits (e.g. Pl. 5, fig. I0) or a number of dark longitudinal lines alternating with light ones (e.g. Pl. I, fig. I), perhaps corresponding to the A and B forms of Lowy \& Hanson (1965).

\section{Table 4. Published reports of fimbriae on bacteria with polar flagella}

\begin{tabular}{|c|c|c|c|}
\hline Bacterial strain & *Diameter & Distribution & References \\
\hline Vibrio cholerae (sic) & $72 \AA$ & Uniform & Tweedy, Park \& Hodgkiss (I968) \\
\hline V. eltor & $79 \AA$ & Uniform & $\begin{array}{l}\text { Barua \& Chatterjee (1964); Tweedy } \\
\text { et al. (1968) }\end{array}$ \\
\hline Caulobacter spp. & $40 \AA$ & Polar & Schmidt ( 1966$)$ \\
\hline Aeromonas hydrophila & & Peritrichous & Page (I962) \\
\hline A. liquefaciens & $79 \AA$ & Peritrichous & Tweedy et al. (1968) \\
\hline Photobacterium splendidum & . & Peritrichous & Houwink \& van Iterson (I950) \\
\hline $\begin{array}{l}\text { Pseudomonas pyocyanea } \\
(P . \text { aeruginosa })\end{array}$ & . & Polar & Houwink \& van Iterson (1950) \\
\hline$P$. aeruginosa & $45 \AA$ & Polar & Bradley (1965, I966) \\
\hline$P$. echinoides & $50 \AA$ & Polar & Marx \& Heumann (1962) \\
\hline & (shadowed) & & Heumann \& Marx (I964) \\
\hline$P$. multivorans & $\begin{array}{c}86 \AA \\
\text { (shadowed) }\end{array}$ & Peritrichous & Tweedy et al. (1968) \\
\hline P. piscicida & & Peritrichous & Hansen, Ingebritsen \& Weeks (1963) \\
\hline
\end{tabular}

Results of shadowing and ultrathin sectioning. Shadowed preparations were made using both strains of Pseudomonas multivorans. Results with respect to distribution of fimbriae confirmed those from negative contrast preparations. However, dimensions and appearances of the filaments were different from those in negative contrast preparations because of the evaporated metal deposit and perhaps because of drying in vacuo. Dimensions of fimbriae are above those which would be expected by extrapolation from negative staining results according to the predictions of Thornley \& Horne (1962) and Tweedy et al. (1968). However, in this study the shadowing material used was different from those used by those workers and the shadowing angle may likewise have been different.

Plate 4, fig. 8 shows cells of strain 0346 of Pseudomonas multivorans in what appears to be transverse section. Extending from the periphery of one of the cells are about I5 straight or slightly curved filamentous structures, 3I to $78 \AA$ wide. Another cell in the same micrograph appears to possess similar appendages. These filaments should not be confused with a finger-like extension on one of the cells which does not appear to be a rigid structure and is 94 to $235 \AA$ wide. It may represent a 'bleb' of cell wall or membrane material seen in thin section. The thin filaments occur all around the periphery of one of the cells seen in section, and may be appendages which are peritrichously distributed on the unsectioned cell. Similar filaments were seen on other sectioned cells of the same strain. Penetration of the filaments into the cell sections was obscured in most cases. The filaments did not display clearly definable substructure in these sections. It would seem likely that these filaments represent the same type of 
appendage as the peritrichous fimbriae seen in negative contrast and shadowed preparations of this strain.

\section{DISCUSSION}

Earlier reports of fimbriae on polarly flagellated bacteria are given in Table 4; there are records of fimbriae on only four species of Pseudomonas, two of which have been re-examined here. In this study, fimbriae were found on eight species of Pseudomonas, six of which had not been examined before by negative contrast staining. Tweedy et al. (1968) state that it has been the experience of one of them in electron microscopic work that fimbriae are possessed by only a few species of bacteria with polar flagella. However, the number of species examined to reach this conclusion was not stated. The results presented here indicate that the ability to produce fimbriae may be a more common feature of pseudomonads than had previously been realized.

Any consideration of the occurrence of fimbriation among different bacterial species must include the interpretation of negative results. The absence of fimbriae on cells of a bacterial strain is a result which may be interpreted in several ways. Not all strains of a species may be genotypically capable of producing fimbriae. Even if they were genotypically fimbriate, organisms may not have been grown under conditions enhancing fimbriation or selecting for fimbriated cells. Another important factor may be examination at a stage of growth when the proportion of fimbriated cells is highest. However, consistently negative results among closely related strains may have some significance. For instance, fimbriae were not observed on Pseudomonas fluorescens (strains 62, 67), P. chlororaphis, or $P$. aureofaciens. Stanier et al. (1966) consider that $P$. chlororaphis and $P$. aureofaciens should be incorporated into the species $P$. fluorescens as biotypes. However, confirmation of these results using other strains is required.

No attempt was made in this study to correlate the presence of fimbriae with haemagglutinating activity. Haemagglutinating activity is not necessarily associated with fimbriae and there are some types of fimbriae without haemagglutinating properties of any kind (Duguid et al. (1966). It is also possible that some types of fimbriae may have adhesive properties but because of restricted distribution on the cell (e.g. monopolar) are unable to confer haemagglutinating properties (Heumann \& Marx, I964). Because of these difficulties most attention was given to electron microscopy in this study. However, preliminary work on haemagglutinating properties of pseudomonads has confirmed the results of Tweedy et al. (1968) with respect to the mannose-sensitive haemagglutinating properties of $P$. multivorans.

The results of Houwink \& van Iterson (1950) on the distribution of fimbriae of Pseudomonas pyocyanea ( $P$. aeruginosa), which were obtained from shadowed preparations, were confirmed in this study by negative contrast staining. Bradley (I966) could not observe the fimbriae of $P$. aeruginosa by negative contrast methods unless cells examined had been treated with a specific RNA bacteriophage. In this study fimbriae were found readily by negative contrast staining of $P$. aeruginosa which had not been deliberately infected with phage. Bradley (1966) found that the diameter of fimbriae of $P$. aeruginosa observed in phage-infected preparations was about $45 \AA$, which is similar to the fimbrial diameter measurements for both strains of $P$. aeruginosa examined in this study (i.e. $54 \pm \mathrm{I}_{4} \AA$ and $52 \pm \mathrm{I} 4 \AA$ ).

Tweedy et al. (1968) found numerous, short, straight fimbriae on cells of Pseudomonas multivorans NCIB 969 I by shadowing. We have observed numerous peritrichous 
fimbriae on two other strains of $P$. multivorans (i.e. 036 B and 0346) by both negative contrast and shadowing methods. In the case of strain 0346 these appendages have also been observed in ultrathin sections. Tweedy et al. (1968) predicted from shadowed preparations of $P$. multivorans NCIB 969I that the diameter of the fimbriae of this strain in negative contrast preparations should be about $60 \AA$. The fimbrial diameter measurement for strain 0346 in this study (i.e. $62 \pm 5 \AA$ ) is very close to that predicted by Tweedy et al. (1968).

The occurrence of polar fimbriae in three biotypes of Pseudomonas solanacearum is of interest; the only other plant pathogenic bacteria so far reported to possess fimbriae are some species of Agrobacterium (De Ley, Bernaerts, Rassel \& Guilmot, 1966). The presence of polar fimbriae on cells of both $P$. acidovorans and $P$. testosteroni is also noteworthy, since these species are considered to be closely related (Stanier et al. 1966).

The fimbriae of Pseudomonas testosteroni and P. fragi appear to exhibit a periodic substructure suggesting that they are composed of repeating subunits of some kind. Regular periodic substructure has been observed before in the fimbriae of several bacteria (e.g. Thornley \& Horne, 1962; Meynell \& Lawn, 1967), including P. echinoides (Heumann \& Marx, I964). The appearance of the filaments of $P$. testosteroni seen in Pl. I, fig. 2 is similar to that of F-actin filaments from muscle seen in negative contrast preparations (Hanson \& Lowy, I963; Haggis, I 966). The model of F-actin substructure constructed by Hanson \& Lowy (1963) consisting of two helically wound strands composed of globular subunits might also apply to fimbriae of similar appearance.

Dark central regions, I3 to $19 \AA$ wide, were seen in fimbriae of strain 0346 of $P$ seudomonas multivorans and $P$. frag $i$ when these were prepared by negative contrast staining. Lawn (I966) has observed central dense lines of maximum diameter I5 $\AA$ in both common fimbriae and F-fimbriae of Escherichia coli when negatively stained. Brinton (1967) states that an axial hole 20 to $25 \AA$ wide occurs in the Type I fimbriae of $E$. coli while the axial hole of F-fimbriae is 25 to $30 \AA$ wide. The central regions seen in the fimbriae of $P$. multivorans and $P$. fragi in this study may indicate that the fimbriae possess axial holes along which negative contrast stain can penetrate, similar to those postulated to exist in Type I fimbriae and F-fimbriae of $E$. coli.

Present classifications of fimbriae are in our opinion artificial and premature. They have already given rise to confusion (Duguid \& Anderson, 1967). No attempt has therefore been made to identify fimbriae of pseudomonads with any of the existing 'Types' in the existing classification schemes.

We wish to stress the possible value of the occurrence and distribution of fimbrialike appendages as taxonomic criteria. With the advent of improved negative contrast staining techniques and the more general use of electron microscopy, such features may be of use in the characterization and identification of bacteria. However, the reproducibility of electron microscopic results and the consistency of fimbriation throughout a particular taxonomic group must be considered. For instance, with respect to the former problem, it is important to know the conditions which are optimal for the production of fimbriae by pseudomonads. Studies on these aspects are proceeding in this laboratory.

We wish to thank Mr D. Gowanlock and Mr J. Hardy of the Electron Microscope Unit, University of Queensland, for assistance in electron microscopy and the Pseudomonas Working Party and Margaret S. Hendrie of the National Collection of 
Industrial Bacteria, Aberdeen, Scotland, for provision of cultures. One of us (J.A.F.) held a University of Queensland Honours Scholarship and a Commonwealth University Scholarship. This work was supported by an Australian Universities Commission Grant.

\section{REFERENCES}

Barua, D. \& Chatterjee, S .N. (1964). Electron microscopy of El Tor vibrios. Indian J. med. Res. $52,828$.

BRADLEY, D. E. (1965). The morphology and physiology of bacteriophages as revealed by the electron microscope. Jl R. microsc. Soc. 84, 257.

BRADLEY, D. E. (1966). The structure and infective process of a Pseudomonas aeruginosa bacteriophage containing ribonucleic acid. J. gen. Microbiol. 45, 83 .

Brinton, C. C. (1965). The structure, function, synthesis and genetic control of the bacterial pilus and a molecular model for DNA and RNA transport in Gram-negative bacteria. Trans. N.Y. Acad. Sci. 27, 1003 .

Brinton, C. C. (1967). Contributions of pili to the specificity of the bacterial surface, and a unitary hypothesis of conjugal infectious heredity. In The Specificity of Cell Surfaces. Ed. by B. D. Davis and L. Warren, pp. 37-70. New Jersey; Prentice-Hall.

De Ley, J., Bernaerts, M., Rassel, A. \& Guilmot, J. (1966). Approach to an improved taxonomy of the genus Agrobacterium. J. gen. Microbiol. 43, 7.

Duguid, J. P. (1966). Note on the terms 'fimbriae' and 'pili'. J. Path. Bact. 92, 137.

Dugum, J. P. \& ANDERson, E. S. (1967). Terminology of bacterial fimbriae, or pili and their types. Nature, Lond. 215, 89.

Duguid, J. P., ANDERSON, E. S. \& CAMPBell, I. (1966). Fimbriae and adhesive properties in Salmonella. J. Path. Bact. 92, I07.

Duguid, J. P., Smith, I. W., Dempster, G. \& Edmunds, P. N. (1955). Non-flagellar filamentous appendages ('fimbriae') and haemagglutinating activity in Bacterium coli. J. Path. Bact. 70, 335 .

Fuerst, J. A. \& HaYward, A. C. (1969). The sheathed flagellum of Pseudomonas stizolobii. J. gen. Microbiol. 58, 239.

HAGGIS, G. H. (1966). The Electron Microscope in Molecular Biology. London: Longmans.

Hansen, A. J., INGEBritsen, A. \& Weeks, O. B. (1963). Flagellation of Flavobacterium piscicida. J. Bact. 86, 602.

HANSON, J. \& Lowy, J. (1963). The structure of F-actin and of actin filaments isolated from muscle. J. molec. Biol. 6, 46.

Heumann, W. \& MarX, R. (1964). Feinstruktur und Funktion der Fimbrien bei dem sternbildenden Bakterium Pseudomonas echinoides. Arch. Mikrobiol. 47, 325.

Hoeniger, J. F. M. (1965). Development of flagella by Proteus mirabilis. J. gen. Microbiol. 40, 29.

HOUWINK, A. L. \& VAN ITERSON, W. (I950). Electron microscopical observations on bacterial cytology. II. A study of flagellation. Biochim. biophys. Acta 5, Io.

LAwn, A. M. (I966). Morphological features of the pili associated with Escherichia coli $\mathrm{K} 12$ carrying $\mathrm{R}$ factors or the F factor. J. gen. Microbiol. 45, 377.

Lowy, J. \& HANSON, J. (1965). Electron microscopic studies of bacterial flagella. J. molec. Biol. II, 293.

LuFT, J. H. (1961). Improvements in epoxy resin embedding methods. J. biophys. biochem. Cytol. 9, 409.

Marx, R. \& Heumann, W. (1962). Über Geißelfeinstrukturen und Fimbrien bei zwei PseudomonasStammen. Arch. Mikrobiol. 43, 245.

MeYNelL, E. \& Lawn, A. M. (1967). Sex pili and common pili in the conjugational transfer of colicin factor Ib by Salmonella typhimurium. Genet. Res. 9, 359.

PAGE, L. A. (1962). Acetylmethylcarbinol production and the classification of aeromonads associated with ulcerative diseases of ectothermic vertebrates. J. Bact. 84, $\mathbf{7 7 2}$.

ReYNolds, E. S. (1963). The use of lead citrate at high $\mathrm{pH}$ as an electron-opaque stain in electron microscopy. J. Cell Biol. 17, 208. 
RICHTER, G. W. \& KREss, Y. (1967). Electron microscopy of a strain of Bordetella bronchiseptica. J. Bact. 94, 1216.

Sabatini, D. D., Bensch, K. \& BarrnetT, N. J. (1963). Cytochemistry and electron microscopy. The preservation of cellular ultrastructure and enzymatic activity by aldehyde fixation. $J$. Cell Biol. 17, 19.

SCHMIDT, J. M. (1966). Observations on the adsorption of Caulobacter bacteriophages containing ribonucleic acid. J. gen. Microbiol. 45, 347.

Stanier, R. Y., Palleroni, N. J. \& Doudoroff, M. (I966). The aerobic pseudomonads: a taxonomic study, J. gen. Microbiol. 43, I59.

THORNLEY, M. J. \& HORNE, R. W. (1962). Electron microscope observations on the structure of fimbriae, with particular reference to Klebsiella strains, by the use of the negative staining technique. J. gen. Microbiol. 28, $5 \mathrm{I}$.

Tweedy, J. M., Park, R. W. A. \& Hodgkiss, W. (1968). Evidence for the presence of fimbriae (pili) on Vibrio species. J. gen. Microbiol. 5I, 235.

\section{EXPLANATION OF PLATES}

Abbreviations in figures: $F$, flagellum; $P$ fimbria.

\section{Plate I}

Fig. I. Pseudomonas aeruginosa ATCC I42I6 after $2 \times 24 \mathrm{hr}+\mathrm{I} \times 22 \mathrm{hr}$ serial subcultures in lactate mineral salts medium incubated at $28^{\circ}$. At least two fimbriae arise from one of the cells. Negatively stained with sodium phosphotungstate, $\mathrm{pH} 7 \cdot 4 \cdot \times 160,000$.

Fig. 2. P. testosteroni ATCC I 1996 after growth for $48 \mathrm{hr}$ in peptone yeast extract broth incubated at $28^{\circ}$. Five fimbrial filaments are visible. Negatively stained with sodium phosphotungstate, $\mathrm{pH} 7 \cdot 0$. $\times 160,000$.

\section{Plate 2}

Fig. 3. $P$. acidovorans ATCC $\mathrm{I} 5668$ after $\mathrm{I} \times 48 \mathrm{hr}+\mathrm{I} \times 72 \mathrm{hr}+\mathrm{I} \times 88 \mathrm{hr}$ serial subcultures in lactate mineral salts medium incubated at $28^{\circ}$. Two fimbriae are visible. Negatively stained with sodium phosphotungstate, $\mathrm{pH} 7 \cdot 0 . \times 80,000$.

Fig. 4. P. alcaligenes ATCC 14909 after growth for $88 \mathrm{hr}$ in peptone yeast extract broth incubated at $28^{\circ}$. One long fimbria is visible, folded across the flagellum in some parts. Negatively stained with sodium phosphotungstate, $\mathrm{pH} 7 \cdot 0 . \times 80,000$.

Fig. 5. P. multivorans strain 0346 after $2 \times 24 \mathrm{hr}+\mathrm{I} \times 20 \mathrm{hr}$ serial subcultures in lactate mineral salts medium incubated at $28^{\circ}$. Numerous peritrichous straight fimbriae are visible. Negatively stained with sodium phosphotungstate, $\mathrm{pH} 7 \cdot 4 . \times 36,000$.

\section{Plate 3}

Fig. 6. P. multivorans strain 0346 after $2 \times 24 \mathrm{hr}+\mathrm{I} \times 22 \mathrm{hr}$ serial subcultures in lactate mineral salts medium incubated at $28^{\circ}$. Several fimbriae are visible, some of which display dark central regions. Negatively stained with sodium phosphotungstate. $\mathrm{pH} 7 \cdot 4 . \times$ I60,000.

Fig. 7. P. multivorans strain 0346 after growth for $22 \mathrm{hr}$ in peptone yeast extract broth incubated at $28^{\circ}$. Numerous peritrichous appendages are visible. Shadowed with platinum/carbon. $\times 44,000$.

\section{Plate 4}

Fig. 8. $P$. multivorans strain 0346 after growth for $26 \mathrm{hr}$ in lactate mineral salts medium incubated at $28^{\circ}$. Numerous filamentous appendages extend from the periphery of sectioned cells. Glutaraldehydeosmium tetroxide fixation. $\times 128,000$.

Fig. 9. $P$. fragi ATCC 4973 after $\mathrm{I} \times 24 \mathrm{hr}+\mathrm{I} \times 39 \mathrm{hr}$ serial subcultures in lactate mineral salts medium. Numerous peritrichous fimbriae are visible. Negatively stained with sodium phosphotungstate, pH 7.0. $\times 52,000$.

\section{Plate 5}

Fig. 10. P. fragi ATCC 4973 after $2 \times 24 \mathrm{hr}+\mathrm{I} \times 22 \mathrm{hr}$ serial subcultures in lactate mineral salts medium at $28^{\circ}$. Straight fimbriae displaying dark central regions are visible. Negatively stained with sodium phosphotungstate, $\mathrm{pH} 7 \cdot 0 . \times 272,000$. 
Journal of General Microbiology, Vol. 58, No. 2

Plate I
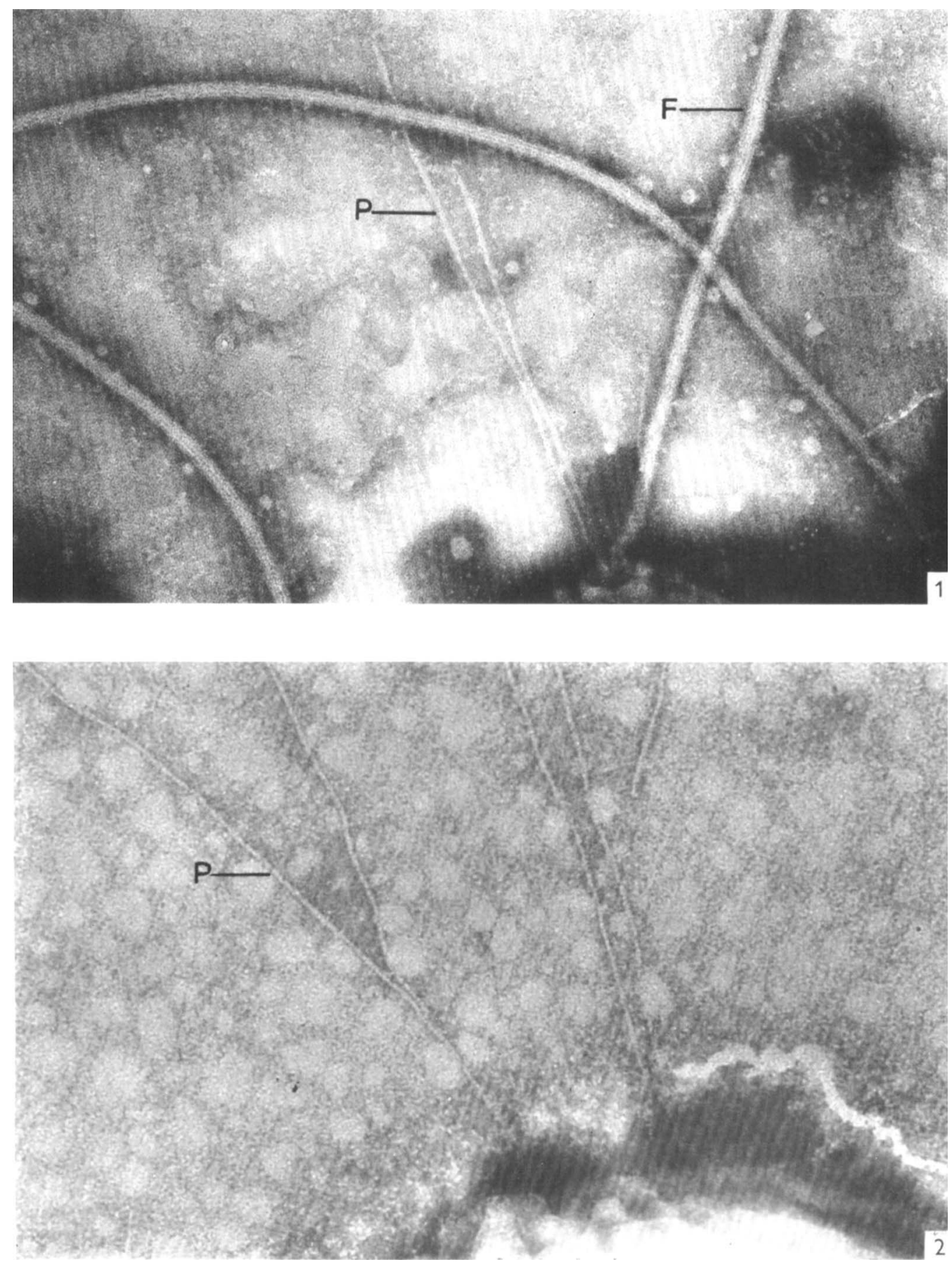

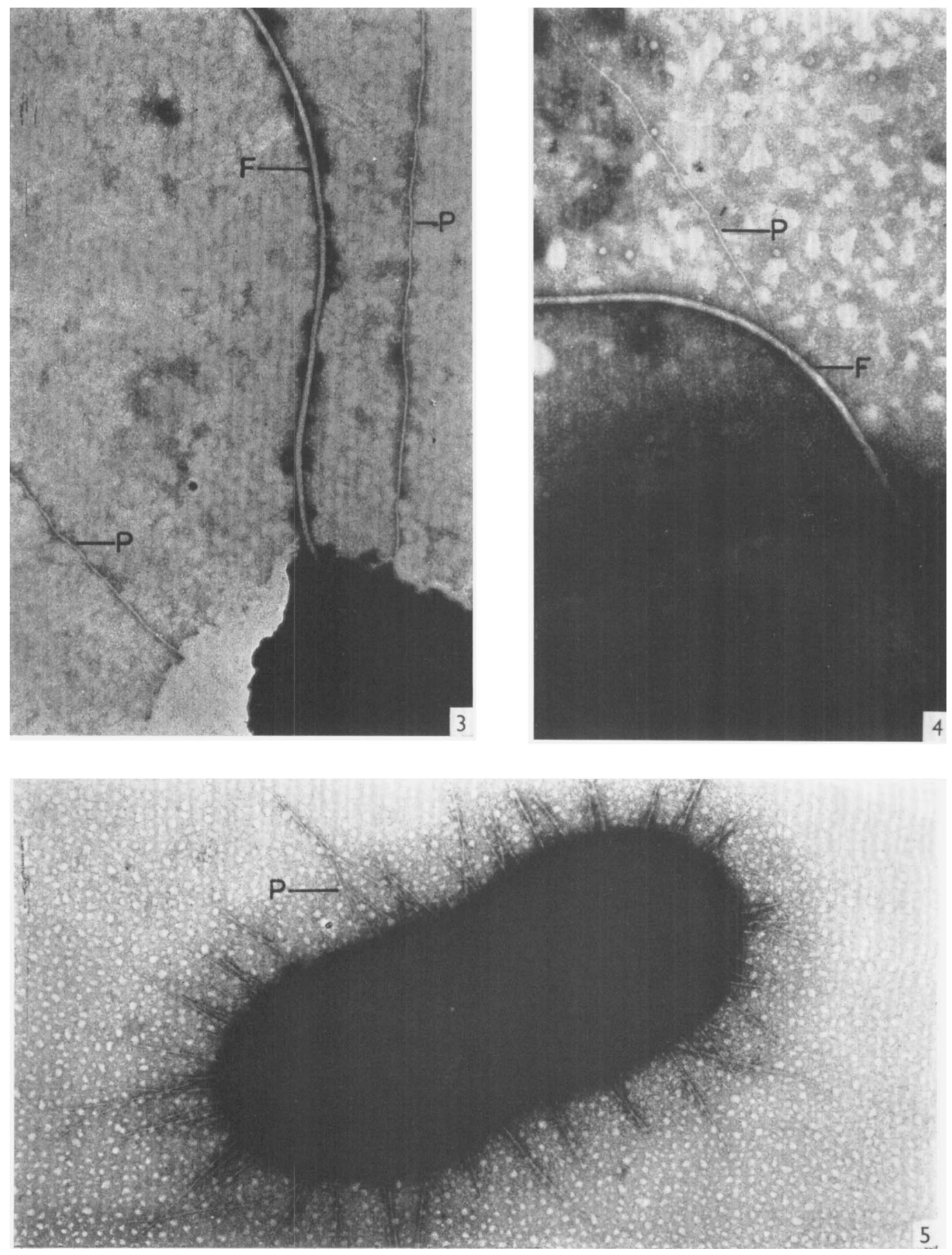

J. A. FUERST AND A. C. HAYWARD 

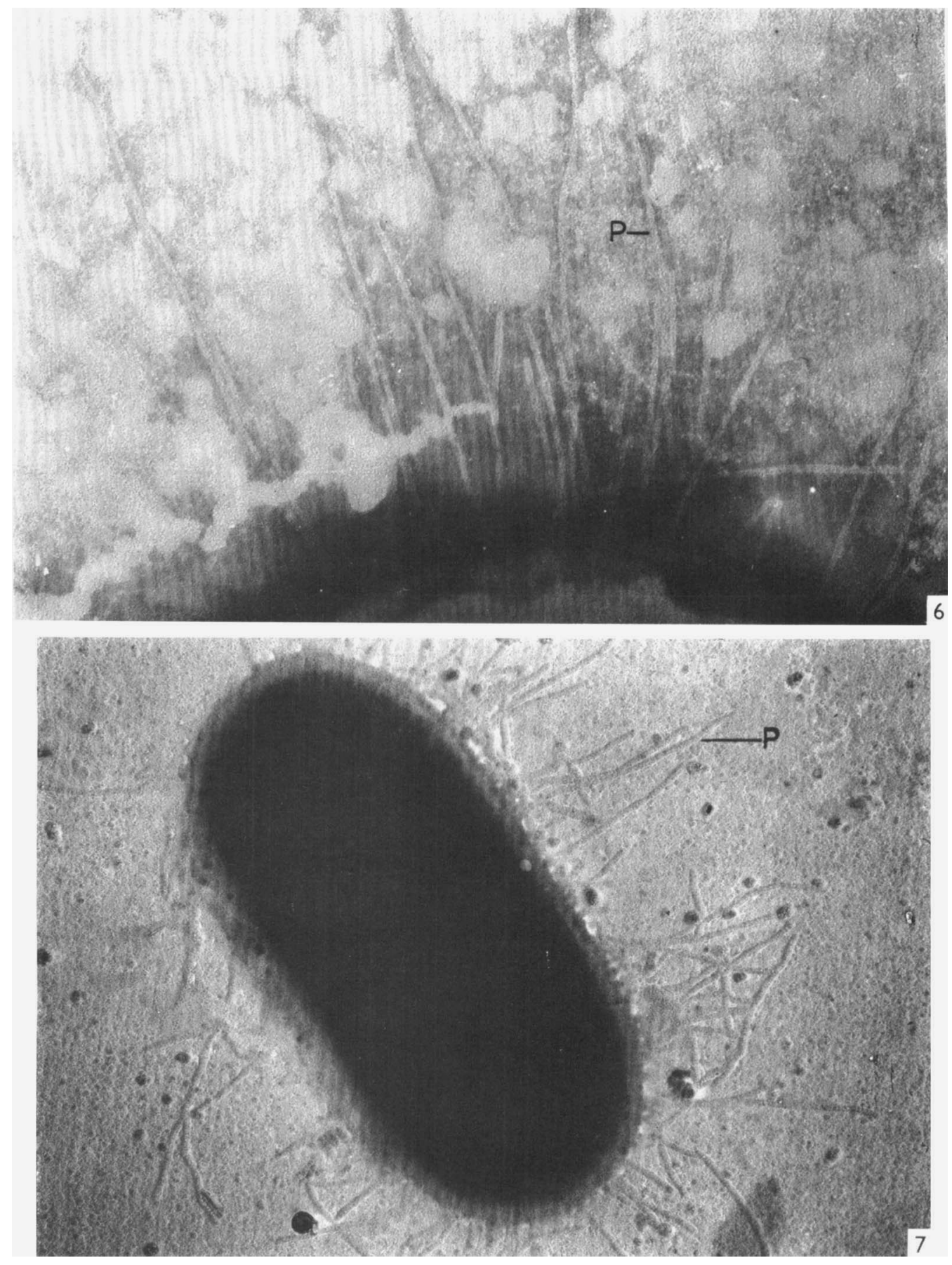

\section{J. A. FUERST AND A. C. HAYWARD}


Journal of General Microbiology, Vol. 58, No. 2

Plate 4
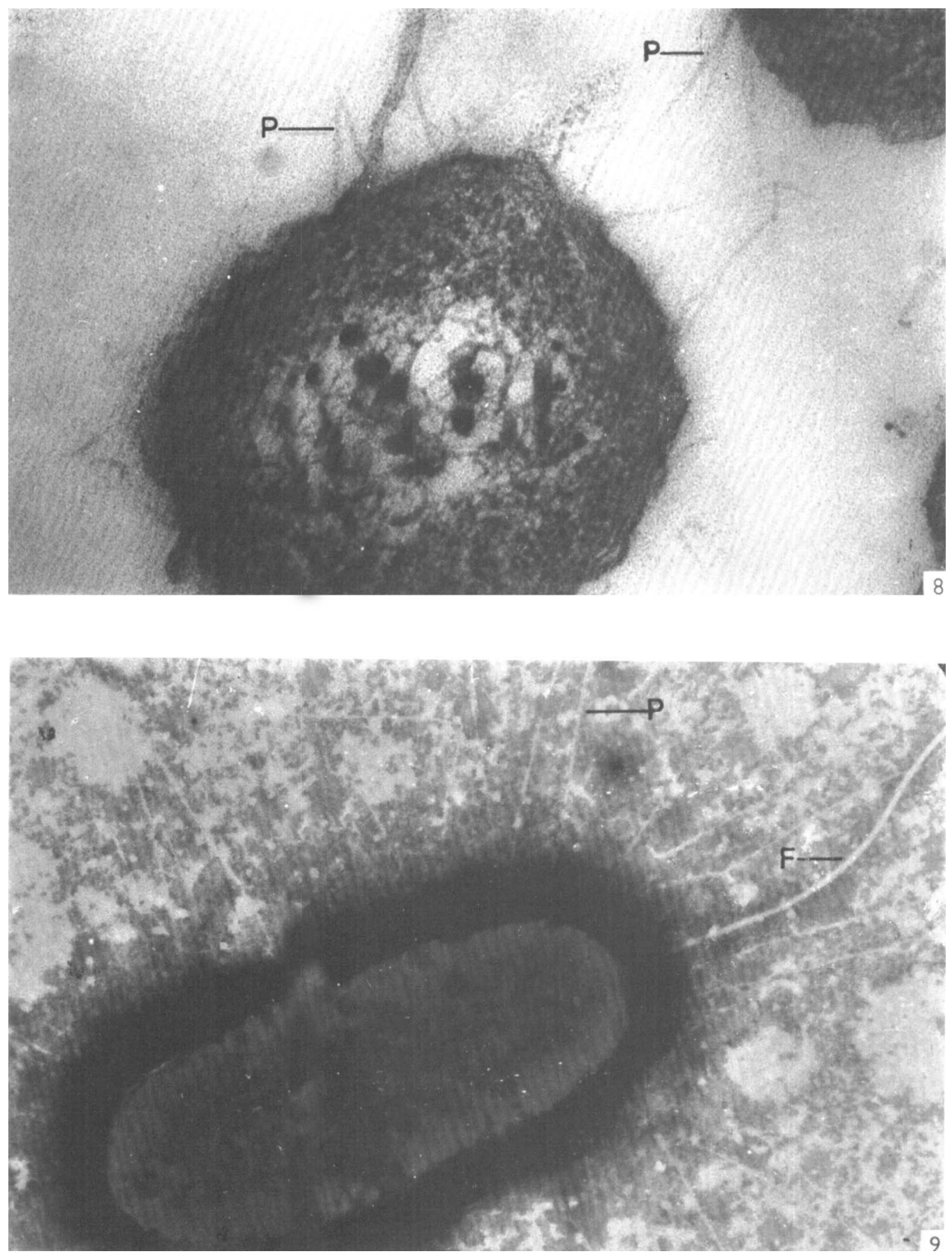

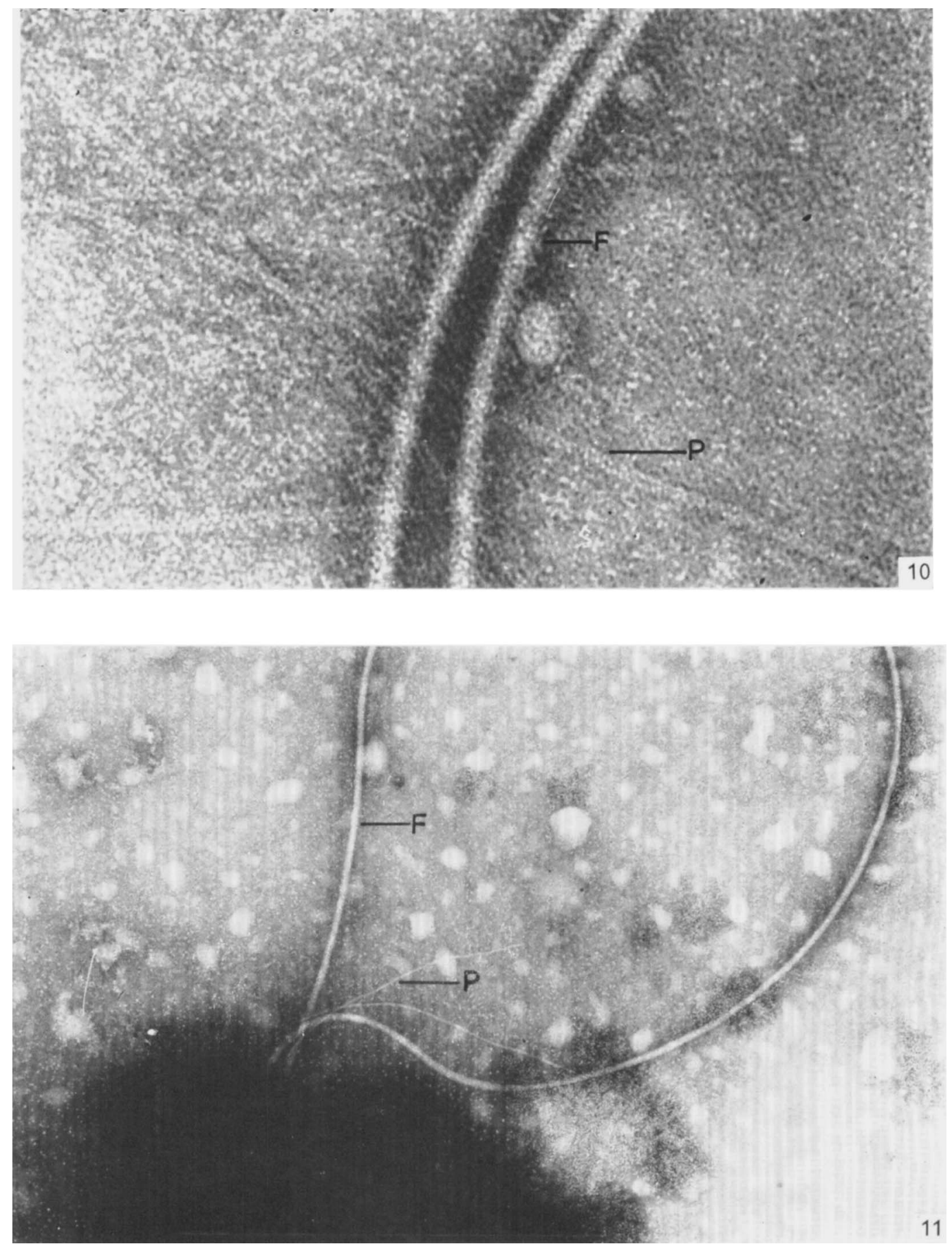

J. A. FUERST AND A C. HAYWARD 

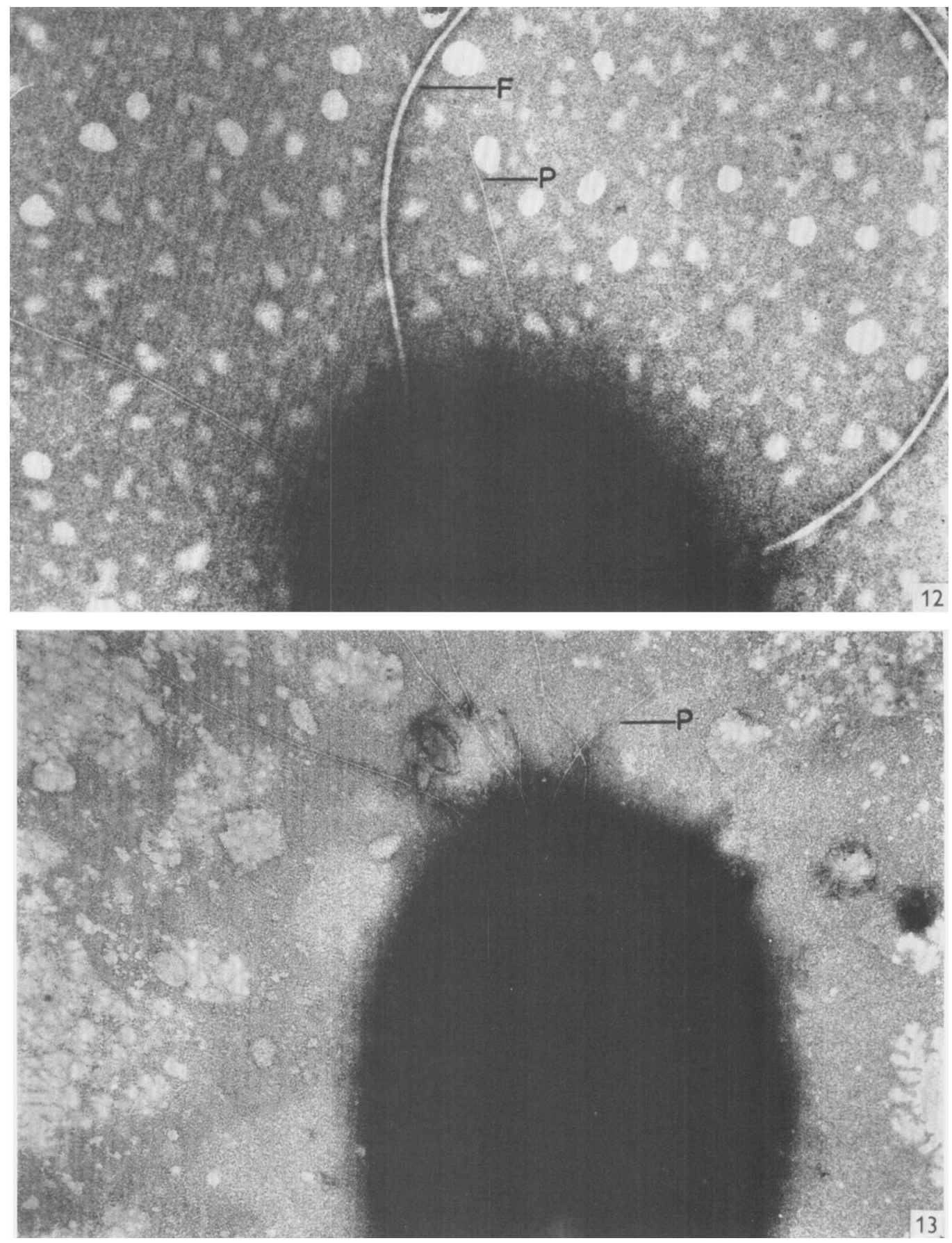

J. A FUERST AND A. C. HAYWARD 
Fig. I I. $P$. maltophilia strain oI 47 after $\mathrm{I} \times 48 \mathrm{hr}+\mathrm{I} \times 72 \mathrm{hr}+\mathrm{I} \times 88 \mathrm{hr}$ serial subcultures in lactate mineral salts medium containing methionine, incubated at $28^{\circ}$. Two curved fimbriae are visible. Negatively stained with sodium phosphotungstate, $\mathrm{pH} 7 \cdot 0 . \times 80,000$.

Plate 6

Fig. 12. $P$. solanacearum strain $017 \mathrm{~A}$, biotype II after growth for $64 \mathrm{hr}$ in sucrose peptone broth incubated at $28^{\circ}$. Three fimbriae extend from a flagellated cell. Negatively stained with sodium phosphotungstate, $\mathrm{pH} 6 \cdot 0 . \times 88,000$.

Fig. I3. $P$. solanacearum strain $002 \mathrm{~A}$, biotype III after growth for $48 \mathrm{hr}$ in sucrose peptone broth incubated at $28^{\circ}$. Six fimbriae extend from one pole of the cell. Negatively stained with sodium phosphotungstate, $\mathrm{pH} 7 \cdot 0 . \times 40,000$. 